\section{PRESENTATION FORM OF PAPERS}

The length of papers is limited to 15 typed pages, single-spaced, including sketch-plans, figures and tables.

Printing will be carried out by a photographic reproduction proceedure which involves a strict respect of the following rules :

a) The manuscripts should be typewritten, single-spaced in the final form (original). For typewriting, please use a film-ribbon or $a$ special ribbon for offset printing. White paper without heading should be used. It should not be folded and should be mailed in a large-envelope, with cardboard, if possible.

b) The surface to be used is $180 \times 230 \mathrm{~mm}$ (see the model overleaf). The photographic reproduction will enable a slight reduction to $160 \times 204 \mathrm{~mm}$ which will result in a better printing uniformity, the elimination of unused spaces, and finally will make possible a general paging and standardized titles.

c) The title of the papers and the authors' names should be given on a separate sheet.

d) An abstract of less than 10 lines should be placed at the beginning of the paper, in both French and English.

e) The text and sketch-plans must be presented within the frame of the model. The first line of the first page of the paper should start at $8 \mathrm{~cm}$ from the top of the page, in order to give the editor the possibility of resetting the standardized titles.

f) The original paging should be written in pencil only.

g) Only black and white pictures will be accepted and will be on printed plates. The proceedure used allows the reproduction of sharp pictures only.

Sketch-plans in black and white will be placed in the text by authors themselves.

NOTA IMPORTANT : the adopted proceedure does not allow corrections by the authors on the printer's proof. Therefore, it is imperative to send the paper in its final form.

\section{REPRINTS}

On request, reprints will be supplied to authors at cost price provided that request is made before the Bulletin is printed.

\section{PRESENTATION DES MANUSCRITS}

La longueur des communications est limitée à 15 pages dactylograpbiées, à interligne simple, y compris les figures, pbotos et tableaux correspondants.

Leur édition sera faite par un procédé de reproduction photographique qui impose le respect strict des règles suivantes :

a) Les communications devront être présentées dans le texte dactylographie original (première frappe) en interligne simple. Pour la dactylograpbie, utilisez dans la mesure du possible, un ruban-film ou un ruban spécial pour offset. On utilisera un papier blanc, sans en-tête, non plié et qui sera expédié sous enveloppe grand format, cartonnée si possible.

b) La surface utile est de $180 \times 230 \mathrm{~mm}$ (voir gabarit au verso). La reproduction photographique permettra une légère réduction à $160 \times 204 \mathrm{~mm}$ qui donnera une plus grande uniformité des caractères, la suppression des fonds de pages et enfin la possibilité de mettre une pagination générale et un titre standardisé.

c) Le titre et le nom du ou des auteurs devront être indiqués sur une page séparée.

d) Un résumé, de moins de 10 lignes, devra être placé en tête de la communication, dans les deux langues employées (français et anglais).

e) Le texte et les figures doivent se trouver obligatoirement à l'intérieur du cadre gabarit. La première ligne de la première page de la communication devra être placée à $8 \mathrm{~cm}$ du baut de la première page, afin de laisser à l'éditeur la possibilité de recomposer les titres standardisés.

f) La pagination d'origine sera notée au crayon seulement.

g) Seules les photos en noir et blanc pourront être acceptées et feront l'objet de planches bors texte. Le procédé employé ne permet que la reproduction de photos bien contrastées.

Les figures en noir et blanc seront disposées dans le texte par les auteurs eux-mêmes.

NOTA IMPORTANT : Le procédé adopté ne permet pas la correction par les auteurs des épreuves d'imprimeur; il est donc nécessaire d'envoyer des manuscrits à texte définitif.

\section{TIRÉS À PART}

Sur demande, des tirés à part pourront être fournis aux auteurs au prix coûtant à condition que demande en soit faite avant l'impression du Bulletin. 